\title{
A Review of Energy and Environmental Management Practices in Cast Iron Foundries to Increase Sustainability
}

\author{
Elena Stefana ${ }^{\circledR}$, Paola Cocca $₫$, Filippo Marciano * ${ }^{\mathbb{D}}$, Diana Rossi and Giuseppe Tomasoni ${ }^{\circledR}$ \\ Department of Mechanical and Industrial Engineering, University of Brescia, via Branze 38, 25123 Brescia, Italy; \\ elena.stefana@unibs.it (E.S.); paola.cocca@unibs.it (P.C.); diana.rossi@unibs.it (D.R.); \\ giuseppe.tomasoni@unibs.it (G.T.) \\ * Correspondence: filippo.marciano@unibs.it; Tel.: +39-030-3715834
}

Received: 7 October 2019; Accepted: 13 December 2019; Published: 17 December 2019

check for updates

\begin{abstract}
Environmental impact and use of energy and materials are relevant topics in companies. To achieve energy savings and enhance environmental performance, managers can invest in technologies (technical measures) and/or implement management practices (low-cost and non-technical measures). This paper focuses on energy and environmental management practices in foundry, which is a particularly energy-intensive industry producing significant carbon dioxide emissions. We conducted a scoping review of scientific publications and technical documents to identify practices that enable energy efficiency improvement and adverse environmental impact reduction in cast iron foundries using coreless induction furnaces. The review returned 399 practices, which we categorised according to the process step of application and theme. We developed a hierarchy to classify the practices according to their sustainability. The results show that the practices proposed in the literature focus mainly on avoiding or reducing resource consumption, rather than on recovering residual value. The intended contribution is to promote the adoption of management practices as an effective lever to increase energy efficiency and reduce environmental impacts, while also providing a summary of current knowledge to facilitate the identification of areas for further research. The review could also support foundry managers in the selection and prioritisation of the practices to adopt.
\end{abstract}

Keywords: non-technical measures; energy saving; environmental performance; environmental impact; literature review

\section{Introduction}

Energy efficiency is an essential task for the future [1]. According to the international standard ISO 50001 [2], energy is "electricity, fuels, steam, heat, compressed air, and other similar media", while energy efficiency is the "ratio or other quantitative relationship between an output of performance, service, goods, commodities, or energy, and an input of energy". The energy efficiency improvement is an important pillar in every industrial sector [3], and one of the key measures for the reduction of carbon dioxide $\left(\mathrm{CO}_{2}\right)$ emissions [4]. Indeed, energy efficiency has a significant impact on the environment [1]. An environmental impact is a "change to the environment, whether adverse or beneficial, wholly or partially resulting from an organization's environmental aspects" [5]; an environmental aspect is referred to an "element of an organization's activities or products or services that interacts or can interact with the environment" [5].

The iron and steel industry plays an important role in such a context: it is highly material and energy intensive [6-8]. Indeed, according to the U.S. Energy Information Administration [9], it is the second-largest user of energy in the world industrial sector, after the basic chemicals industry. From 
an environmental point of view, air emissions are the key concern. The iron and steel industry is one of the biggest industrial emitters of $\mathrm{CO}_{2}$, accounting for between $4 \%$ and $7 \%$ of anthropogenic $\mathrm{CO}_{2}$ emissions globally [8-10]. In addition, the foundry process generates mineral dusts, acidifying compounds, products of incomplete combustion, and volatile organic carbons.

Foundries represent an important part of the iron and steel industry and, thus, are characterised by the same energy and environmental issues described above. Several authors underline the energy intensive nature (e.g., [11,12]) and the environmental impacts (e.g., [13]) of a foundry. In this sense, Patange and Khond [13] state "reports from many foundries suggest that energy efficiency is one of the most significant cleaner production options still to be addressed in the industries".

As underlined by Lo et al. [14], companies can adopt both technical and non-technical measures for improving their sustainability. Both academic research and policy documents in the fields of enhanced energy efficiency and environmental performance have so far focused mainly on technology implementation $[15,16]$. However, technology adoption usually requires large capital investments that may represent a barrier for many companies [17,18].

In addition, empirical studies have demonstrated that technology is not the only way to achieve improvements [19-21]. Indeed, a cost-effective way is the adoption of non-technical measures such as management practices $[15,16,22]$. A management practice can be defined as a strategy for managing a plant's operational activities in order to produce a desirable outcome. Energy and environmental management practices are those systematic activities, procedures, and routines within an industrial company including strategy/planning, implementation/operation, controlling, organisation, and culture, and involving both production and support processes, which aim to continuously reduce the company's energy consumption and adverse environmental impact [16,23]. The term 'practice' as opposed to 'technology' refers to the implementation of low-cost measures such as staff training, changes in day-to-day routines, and the adoption of processes without increasing operating costs [15]. According to Caffall [19], these practices enable relevant savings without capital or with limited investment and short payback time compared to that of a technical measure. Such savings could then be used to finance subsequent investment in efficient technologies. For these reasons, several authors advocate the promotion of management practices as an effective lever for enhancing production systems and operations towards improved energy efficiency and environmental performance [16,21]. Despite their potential to largely contribute to these objectives, practices have been scarcely studied in literature and applied in companies [3,15,16,24]. For example, research by Thollander and Ottosson [24] revealed that only $25 \%-40 \%$ of companies in energy-intensive sectors in Sweden could be classified as successful in energy management. Moreover, it has been demonstrated that one of the key barriers to energy efficiency in companies is a lack of information about energy efficiency measures [25].

To fill these gaps, the objective of this paper is to conduct a scoping review of the literature to identify energy and environmental management practices for energy efficiency improvement and adverse environmental impact reduction specific to the foundry industry. In order to limit the scope of the research, our focus is represented by practices that can be implemented in foundries producing cast iron, which has a low melting point and a good casting ability in comparison to steel [26]. We will consider only foundries using coreless induction furnace, which is gradually gaining higher market preference compared to the cupola one and is increasingly being implemented [26], also because it produces heat cleanly, without combustion [27]. For each practice, the process step(s) to which it could be applied will be specified.

The paper is organised as follows. In Section 2, a description of the various steps of the foundry process will be provided. Section 3 will present the review methodology adopted. Results will be summarised and discussed in Sections 4 and 5. Conclusions and directions for future research will be available in the last section. 


\section{Foundry Process}

A typical foundry process is composed of various steps that allow producing finished castings starting from scrap or ingots. It is a rather complex process where metal, energy, sand, binders, and water are the main input streams, while dust, amines, and volatile organic compounds (VOCs) are the major key emissions [26]. Other not negligible outputs are heat, sand and chemicals, odour, and noise [26].

Figure 1 depicts an overview of a foundry process for making cast iron through an induction melting furnace. The main reference of Figure 1 and the description below is the Reference Document on Best Available Techniques in Foundries by the European Commission [26]. Examples of other interesting information sources are Lazzarin and Noro [28] and Gandhewar et al. [27].

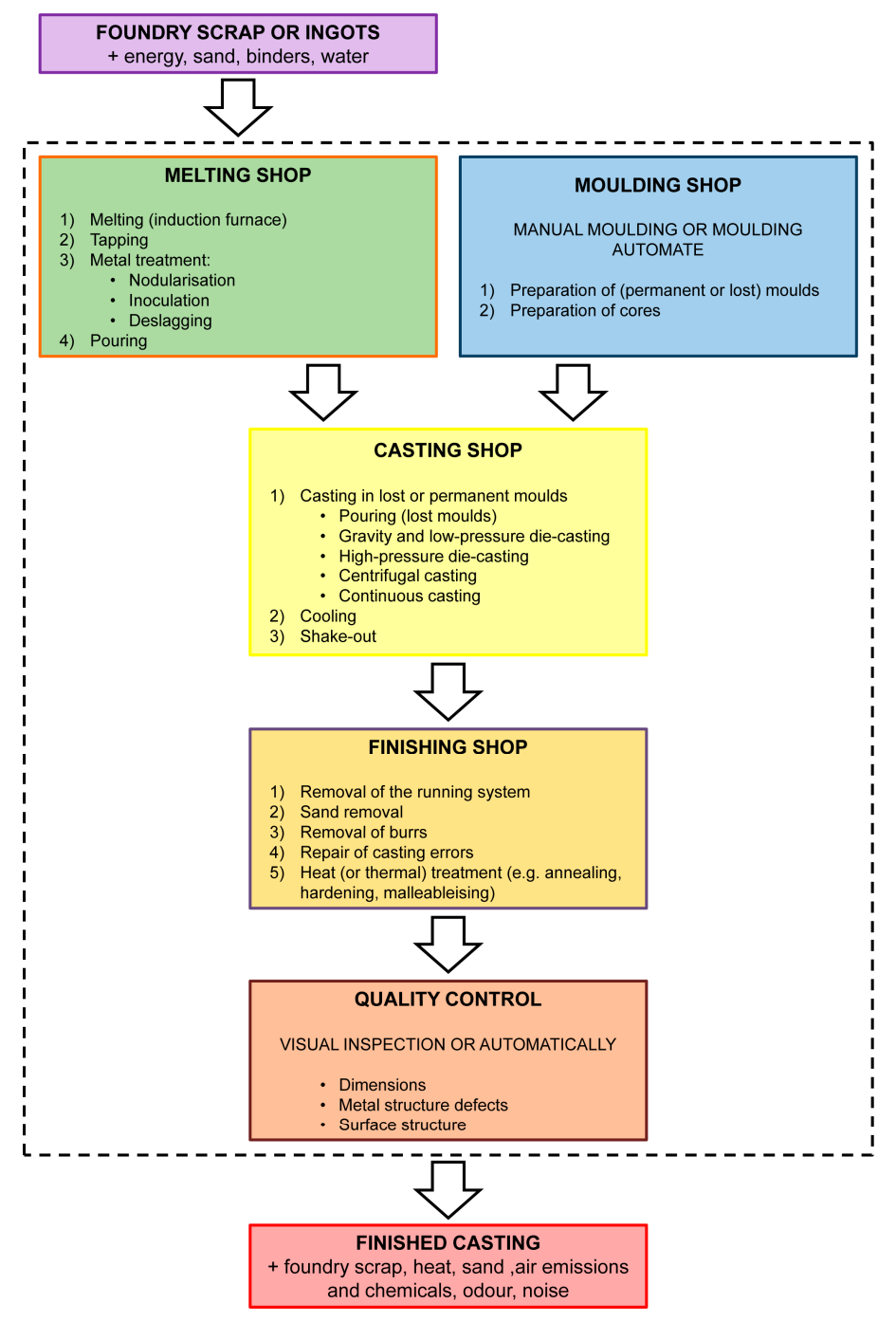

Figure 1. Foundry process for cast iron production. Adapted from [26].

The foundry process begins with melting operations, as shown in Figure 1. For obtaining the molten metal (achieved at about $1450-1500{ }^{\circ} \mathrm{C}$ based on the type of the cast iron, in accordance with $[28,29])$, the foundry consumes a lot of energy. In particular, the melting shop represents the major energy consumption department $[13,28,29]$, responsible of $55 \%-80 \%$ of the total energy consumed in a foundry $[11,12,30-32]$.

We focus on melting realised thanks to an induction furnace. According to the European Commission [26], this type of furnace is gradually gaining higher market preference compared to the cupola one and is increasingly being implemented. In accordance with Gandhewar et al. [27], 
industrial induction melting furnaces produce their heat cleanly, without combustion. There are two types of induction furnaces, which are coreless and channel ones. In particular, coreless induction furnaces are used for melting, while channel induction furnaces are only used for holding. The coreless induction furnace may be completely emptied and restarted easily [27].

A coreless induction furnace features an external insulated part and an internal part that is refractory lined $[28,29]$. Generally, this type of furnace has electricity as the energy source. The coreless induction furnace requires ferrous material, alloying metal, carburising agents, and cooling water as inputs, and provides metal alloy (e.g., cast iron), dust, organic and metallic fumes, carbon monoxide, slag (about 10-20 kg slag per tonne of metal charge; however, the amount of slag produced depends on the quality of the charge material), and refractory waste. The highest emission rates occur during charging and at the beginning of the melting cycle. The European Commission [26] reports some data about emission rates of particulate matter: $0.06-1 \mathrm{~kg} /$ tonne of metal charge have been reported in the literature, but values of $0.04-3 \mathrm{~kg} /$ tonne are normal. However, the majority of the emission depends on the cleanliness and the composition of the charged material.

The European Commission [26] highlights that the energy consumption of a coreless induction furnace depends on its size and working regime, while the energy level of a channel induction furnace is based on process-related parameters, such as the holding time. Important aspects about the energy consumption of a coreless induction furnace are represented by heat losses, such as transmission losses, radiation losses without lid, coil losses, and lining-conducted heat losses.

The molten metal is then held for short-term periods and transported through ladles, which are vessels with an insulation of different layers of lining for reducing the level of overheating and the required time for pre-heating [28].

The moulding shop is the department of a foundry that produces moulds and cores. In particular, moulding regards the making of a mould in which the molten metal is poured in order to obtain a piece of the desired shape. Depending on the types of moulds (permanent or lost ones), the moulds can be metallic or made of sand and chemically bonded, clay-bonded, or unbonded. This department involves mixing sand with different chemicals and emits gaseous or volatile reaction products and excess reagents. The European Commission [26] reports some details and data about air emissions and other environmental impacts of the different binder types.

Consequently, the molten metal and the finished moulds represent the inputs of the casting shop in the case of lost moulds, while the molten metal, the cores, the water-based release agent, and the cooling water are the inputs of the casting shop if the moulds are permanent. In this foundry department, the molten metal fills the mould for obtaining a casting, which then is cooled to allow solidification and finally removed from the mould. Casting can be performed manually or using a pouring machine [29].

In particular, the casting in lost moulds comprises several steps, such as pouring (with lip pour or teapot ladles), solidification or first cooling (sometimes, through the transportation of the poured moulds along a line whose length determines the final temperature of the casting), shake-out (i.e., the separation among the casting, the moulding box, and the sand), and finally casting cooling or second cooling. In addition to castings, these operations produce used sand, combustion products, organic pollutants from pyrolysis and thermal degradation of binder, blackened moulds, odour, waste from exhaust air cleaning, and dust from shake-out. Combustion gases and volatile compounds are generated during the preheating of ladles and during cooling and shake-out, respectively. In general, during pouring, fumes and/or vapours and chemical compounds from the binder and some blackening systems can be released. However, the type of emissions during casting is dependent on the binder type used and their levels are comparable to those during the mixing stage, with the addition of pyrolysis products. Note that a lower sand-to-liquid metal ratio can reduce the total volume of sand in the system and, thus, reduce the consumption of new materials. In the step of casting, the circulating scrap and the sand are recovered to be regenerated and reused [26,29]. 
For casting in permanent moulds, several techniques are available (Figure 1). In this case, oily mist, organic pollutants, metal oxides containing dusts, dust, and wastewater can be produced as outputs. Emission and consumption levels depend on the type of alloy used, the surface area of the melt, the quantity of sand cores inserted in the mould, and the surface/volume rate of the casting. Furthermore, the electricity consumption is based on process aspects (e.g., the closing force of the die).

After casting operations, finishing of the raw casting is needed in order to obtain finished castings. Some possible required treatments are listed in Figure 1. The main inputs of this step are abrasives, water, and electricity, while the outputs are dust from mechanical operations, volatised metals and combustion products from thermal operations, and wastewater.

If necessary, finishing and post-casting operations require a step of heat treatment. Examples of these thermal treatments are annealing (i.e., the tension caused in the workpiece and the subsequent cooling down of the casting are reduced and the structure is evened out), hardening or quenching (i.e., the level of heat is raised above the transformation temperature and the workpiece is subsequently rapidly cooled), and malleableising (i.e., the malleable unfinished casting is transformed to a white or black temperature casting). The heat treatment produces combustion products from firing, water vapour, fume, oil mist, $\mathrm{NO}_{\mathrm{x}}$, and $\mathrm{SO}_{2}$. Furthermore, emissions derived from heat treatment furnaces include combustion gases, whose composition depends on the fuel type used. Note that emission levels are related to energy consumption, burner design, and maintenance.

Finally, the quality control checks the compliance of the product and, if the requirements are not met, castings are rejected and then remelted.

In addition to all these production processes, in a foundry, there are also 'horizontal' activities that are service plants (also called 'plant services', 'support processes', or 'non-production processes'). These service plants support the overall process of obtaining finished castings: e.g., production and distribution of compressed air and hydraulic systems for the activation of the equipment and machine tools, lighting, heating and/or conditioning of the department of the company, handling, and purification 'end-of-pipe' processes.

\section{Methods}

The purpose of this review is to answer the following research question: 'Which management practices could be adopted to improve energy efficiency and to reduce adverse environmental impacts in a cast iron foundry?'. This research question is extremely broad, since our aim is not to focus on a specific category of practices or energy/environmental benefits, but to identify all possible practices leading to some benefits and classify them. For this reason, it is not advisable to use a systematic review approach, since it would generate an unmanageably large number of references, but it is recommended to carry out a scoping review [33]. A scoping review is a form of knowledge synthesis comprehensively summarising evidence with the aim of informing practice, programs, and policy and providing direction to future research priorities [34]. Scoping reviews are relevant to both emerging and established fields. In established fields where there may be an abundance of evidence, as in the topic under investigation in this paper, scoping reviews can provide an understanding of the "lay of the land" [34]. Indeed, one of the objectives of scoping studies is to summarise and disseminate research findings to practitioners who might otherwise lack time or resources to undertake such work themselves $[33,35]$. In addition, review results presented in an accessible and summarised format facilitate an effective use of the findings [33].

After the definition of the research question, the next step of a scoping review is the identification of relevant studies. Since the whole point of scoping the field is to be as comprehensive as possible in identifying studies answering the research question, we adopted a strategy that involved searching for research evidence via different sources: electronic bibliographic databases; reference lists; existing networks; relevant organisations and conferences. The process adopted for identifying literature was not linear but iterative, requiring researchers to engage with each stage in a reflexive way and, where necessary, repeat steps to ensure that the literature is covered in a comprehensive way. Indeed, as 
familiarity with the literature increased, we refined the search strategy and the search terms. The initial set of keywords for the search was provided by the research question. For each of the keywords, we identified various synonyms for intercepting the larger set of possible relevant publications. Some examples of the terms employed in the search are: practic* ${ }^{*}$, foundr* ${ }^{*}$ improve ${ }^{*}$, energy, environment*, sustainabil*, emission*, pollutan*, furnac*, and consumpt* (the asterisk allows including any variation of the searched terms).

We combined these terms to define different search strings to implement in multiple electronic databases of scientific publications. Particularly, we used ScienceDirect, Scopus, and Web of Science as electronic databases for conducting the review. The review covered only English-language papers and included also conference proceedings.

In addition to journal publications and conference papers, we were interested in standards and technical papers, e.g., reports derived from European and/or international projects on the review topic. These documents were retrieved through specialised or general search engines (e.g., Science.gov) and sites of organisations for standardisation (e.g., International Organization for Standardization). We also contacted relevant national and international organisations working in the sector and trade associations. Additional studies were identified by checking the bibliographies of the studies found through previous searches.

The selection of the studies to include in the review was performed in parallel by two researchers. The first reading was restricted to title and abstract/summary (if present), and then the full text was analysed. Publications solely on the technology implementation or other aspects of a foundry (e.g., safety issues) were excluded. A third reviewer was added in situations of disagreement to determine final inclusion.

After identifying all the relevant articles, the full text was screened to identify the management practices proposed. Duplicate practices were synthesised into a single entry.

We divided practices into two main groups: general management practices and specific practices. In order to categorise specific practices according to their sustainability, we developed the reference framework in Figure 2 based on the 'waste hierarchy' proposed by the European Union [36] and its extended version, the 'resource hierarchy' [37].

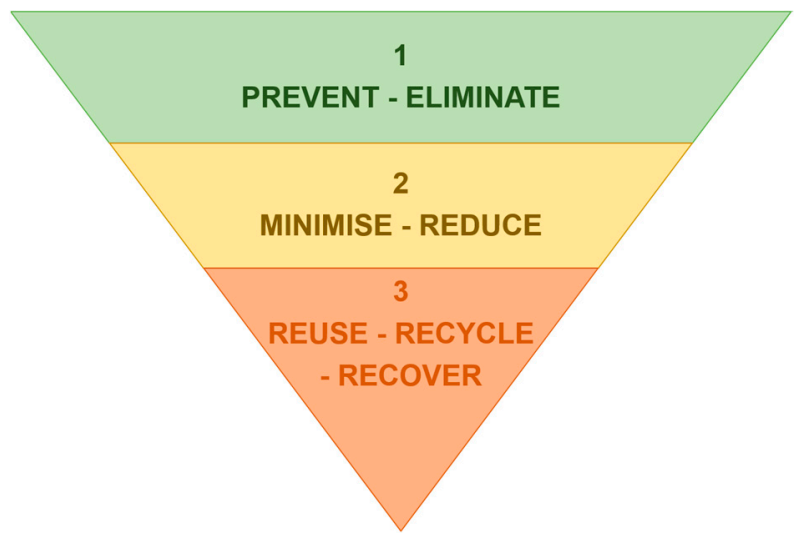

Figure 2. Energy and environmental management practices hierarchy. Adapted from [36,37].

From the sustainability point of view, the preferred option is to prevent or eliminate the consumption of a resource or an adverse environmental impact. Therefore, we classified as Type 1 all the practices that eliminate an energy demand or environmental impact altogether. These practices are generally concerned with the efficient design or redesign of the production plant or its facilities, or the shift to a cleaner fuel or material. They are usually carried out 'una tantum'. Type 2 practices are those that enable the use of less resource to meet the need or to reduce/minimise the connected environmental impact. They are usually activities performed on an ongoing basis. Minimisation is clearly a less-sustainable option, and thus less preferable, than elimination. Finally, Type 3 category 
includes all the practices that deal with the reuse, recycling, or recovery of resources. This means re-introducing the resource into the same flow, using it in a different flow, or capturing some residual value. It is necessary to underline that the adoption of Type 1, Type 2, or Type 3 practices does not ensure that a foundry is actually sustainable, since there are other environmental, social, and economic aspects to consider. The above-mentioned practices are only able to contribute to foundry sustainability.

\section{Results}

The practices identified through the literature review are synthesised into tables. Tables 1 and 2 present general management practices for energy management and for environmental management, respectively. They consist of high-level principles, which could be applied across all industries. The general energy and environmental management principles are then operationalised into more specific practices, i.e., activities, procedures, and routines. Due to length constrains, the tables listing all specific practices are not included in the paper but are available as supplementary materials. In particular, Table S1 gathers the practices common to all process steps in a cast iron foundry, Table S2 provides the practices specific to each step, and Table S3 summarises the management practices for utilities and support processes. In Tables S1-S3, for each theme, Type 1 practices are listed first, followed by Type 2 and Type 3. In this paper, we provide only a summary of the specific practices. Indeed, Table 3 shows an overview of the themes tackled, along with information on the references and the number and types of practices identified. 
Table 1. General energy management practices.

\begin{tabular}{|c|c|c|}
\hline Scope & Practice & References \\
\hline \multirow[t]{2}{*}{ Energy management system } & $\begin{array}{l}\text { Manage energy, adjusting and optimising it, using systems and procedures to reduce energy } \\
\text { requirements per unit of output by keeping constant or reducing the total costs of producing the } \\
\text { output from these systems. The energy management consists of planning, execution, and control steps. }\end{array}$ & {$[3,6,11,13,15,16,21,38-50]$} \\
\hline & $\begin{array}{l}\text { Implement an Energy Management System (EnMS), specifically according to standard ISO } 50001 \text { [2] } \\
\text { and integrate it into the broader industrial management system. }\end{array}$ & {$[2,6,16,22,29,38,40-43,45,47,48,51-56]$} \\
\hline \multirow[t]{2}{*}{ Energy policy and programs } & $\begin{array}{l}\text { Have a long-term energy strategy and define an energy policy stating the organisation's commitment } \\
\text { to achieve energy performance improvement. }\end{array}$ & {$[2,15,16,40-42,45,46,48,51,57]$} \\
\hline & $\begin{array}{l}\text { Plan energy targets and objectives and develop an energy management program, also based on the } \\
\text { results of the implementation of a self-assessment tool (e.g., Energy Management Matrix by Carbon } \\
\text { Trust [58]). }\end{array}$ & {$[16,22,30,38,40-43,45-48,51,55,58-60]$} \\
\hline $\begin{array}{l}\text { Energy monitoring, measurement and } \\
\text { control }\end{array}$ & $\begin{array}{l}\text { Quantify the theoretical energy requirements, monitor and control the amount of energy used } \\
\text { (defining energy indicators, i.e., Key Performance Indicators, KPIs, or Energy Performance Indicators, } \\
\text { EnPIs) to determine where and how energy is being consumed and how efficient are the processes. } \\
\text { Particularly, refer to standard methodology, e.g., EN } 16212 \text { [72], ISO } 50001 \text { [2], ISO } 50006 \text { [73], for cost } \\
\text { and energy savings calculations. }\end{array}$ & {$[3,4,6,11-13,16,21,28,29,40-42,45-49,52,53,58,61,63,69,72-81]$} \\
\hline Energy benchmarking & $\begin{array}{l}\text { Use benchmarking to compare the energy efficiency performance of own processes with those of } \\
\text { others (industry average or best-practice benchmark), with own performance at an earlier time } \\
\text { (historical benchmark), or with own similar processes (company-wide or internal benchmark). } \\
\text { Particularly, refer to an energy efficiency benchmarking methodology according to EN } 16231 \text { [82]. }\end{array}$ & {$[2,4,16,22,28,38,40,42,46,52-54,58,75,82-84]$} \\
\hline $\begin{array}{l}\text { Training, communication and } \\
\text { involvement }\end{array}$ & Assure commitment from top management to support the energy programs. & {$[3,16,40-42,45-47,52,57]$} \\
\hline Continual improvement & $\begin{array}{l}\text { Continually improve the energy management: consider the energy management as a process and not a } \\
\text { project which eventually comes to an end. Refer to frameworks, tools and strategies typical of the } \\
\text { quality management, e.g., PDCA (Plan Do Check Act) or 7Epsilon. }\end{array}$ & {$[2,16,41-43,45,48,53,61,76,87]$} \\
\hline Energy modelling and simulation & $\begin{array}{l}\text { Use computer programs and software tools for modelling and simulation of process operations and } \\
\text { energy flows to identify energy saving opportunities. }\end{array}$ & {$[1,6,11,16,22,30,32,40-42,46,48,53,61,63,75,80,81,85]$} \\
\hline \multirow[t]{3}{*}{ Energy manager and/or team } & $\begin{array}{l}\text { Employ a (full-time) energy manager, close to the CEO, responsible for energy consumption, internal } \\
\text { communication, and effectiveness of the energy management program and equipped with the } \\
\text { necessary authority for energy efficiency investments. }\end{array}$ & {$[3,15,16,21,38,41,48,49,51]$} \\
\hline & $\begin{array}{l}\text { Form an energy team (or Energy Management Committee, EMC) with personnel in operation, } \\
\text { maintenance, administration, management, financing, and governing. }\end{array}$ & {$[2,16,41,45]$} \\
\hline & $\begin{array}{l}\text { Assess the possible support of an Energy Service Company (ESCO) in providing technical and } \\
\text { economic information about energy management solutions and managing the interventions. }\end{array}$ & {$[42,51,57]$} \\
\hline
\end{tabular}


Table 2. General environmental management practices.

\begin{tabular}{|c|c|c|}
\hline Scope & Practice & References \\
\hline \multirow[t]{2}{*}{ Environmental management system } & $\begin{array}{l}\text { Manage environmental aspects using systems, procedures, practices, and services to avoid, reduce, or } \\
\text { control the creation, emission, or discharge of any type of pollutant or waste, reduce adverse } \\
\text { environmental impacts, and enhance environmental performance. }\end{array}$ & {$[5,6,22,26,42,48,88-92]$} \\
\hline & $\begin{array}{l}\text { Implement an Environmental Management System (EMS), particularly according to standard ISO } \\
14001 \text { [5] or adopting the EU Eco-Management and Audit Scheme (EMAS) [93] and integrate it into the } \\
\text { broader industrial management system. }\end{array}$ & {$[5,6,22,26,41,42,48,53,88,89,91,94]$} \\
\hline \multirow[t]{2}{*}{ Environmental policy and programs } & $\begin{array}{l}\text { Have a long-term environmental strategy and define an environmental policy stating the } \\
\text { organisation's commitment to achieve environmental performance improvement. }\end{array}$ & {$[5,6,26,42,81,88,94,95]$} \\
\hline & $\begin{array}{l}\text { Plan environmental targets and objectives and develop an environmental management program to } \\
\text { prevent or mitigate adverse environmental impacts from both normal operations and emergencies. }\end{array}$ & {$[5,6,26,41,88-90,95,96]$} \\
\hline Environmental audits & $\begin{array}{l}\text { Conduct in-depth environmental audits on a regular basis to analyse key characteristics of operations } \\
\text { and activities that can have significant environmental impacts and/or compliance consequences. } \\
\text { Conduct environmental audits (internal and/or external-supplier or third-party auditing) according to } \\
\text { ISO } 19011 \text { [68]. }\end{array}$ & {$[5,6,26,42,68,88,90,95,97]$} \\
\hline $\begin{array}{l}\text { Environmental monitoring, } \\
\text { measurement and control }\end{array}$ & $\begin{array}{l}\text { Quantify, monitor, and control resources consumption, the amount of waste, and emissions, preferably } \\
\text { with a continuous monitoring, to determine where and how resources are consumed and where and } \\
\text { how waste and emissions are produced. }\end{array}$ & {$[5,6,26,42,47,77,88-92,96-99]$} \\
\hline Environmental benchmarking & $\begin{array}{l}\text { Use benchmarking to compare the environmental performance of own processes with those of others } \\
\text { (industry average or best practice benchmark), with own performance at an earlier time (historical } \\
\text { benchmark), or with own similar processes (company-wide or internal benchmark). }\end{array}$ & {$[6,22,26,77,88,90,91,97-99]$} \\
\hline \multirow[t]{2}{*}{$\begin{array}{l}\text { Training, communication and } \\
\text { involvement }\end{array}$} & $\begin{array}{l}\text { Internally and externally communicate information relevant to the environmental management; } \\
\text { increase the employees' competence on and the awareness of environmental aspects and impacts } \\
\text { associated with their work. Permanently motivate co-workers. }\end{array}$ & {$[5,6,22,26,41,61,88,89,91,94,95,97-99]$} \\
\hline & Assure commitment from top management to support the environmental management programs. & {$[5,6,26,41]$} \\
\hline Continual improvement & $\begin{array}{l}\text { Continually improve the environmental management. Refer to frameworks, tools, and strategies } \\
\text { typical of the quality management, e.g., PDCA. }\end{array}$ & {$[5,6,26,41,42,53,91,92,97,98]$} \\
\hline \multirow[t]{2}{*}{$\begin{array}{l}\text { Environmental modelling and } \\
\text { simulation }\end{array}$} & $\begin{array}{l}\text { Use computer programs and software tools for modelling and simulation of operations and flows to } \\
\text { evaluate actual and predict potential level of resource consumption or waste/emissions (particularly } \\
\mathrm{CO}_{2} \text { or dispersion model) and identify environmental opportunities. }\end{array}$ & {$[6,30,48,61,77,81,90]$} \\
\hline & $\begin{array}{l}\text { Compile and evaluate inputs, outputs, and potential environmental impacts of a product, process, or } \\
\text { system throughout its life cycle using Life Cycle Assessment (LCA), specifically according to ISO } \\
14040 \text { [100] and ISO } 14044 \text { [101]. }\end{array}$ & {$[6,94,98,100-102]$} \\
\hline Environmental team & $\begin{array}{l}\text { Set up an environmental team responsible for EMS implementation and monitoring and for } \\
\text { establishing and achievement of environmental programs. }\end{array}$ & [95] \\
\hline
\end{tabular}


Table 3. Overview of specific management practices.

\begin{tabular}{|c|c|c|c|c|c|c|c|}
\hline \multirow{2}{*}{ Group } & \multirow{2}{*}{ Process STEP } & \multirow{2}{*}{ Theme } & \multirow{2}{*}{ References } & \multicolumn{3}{|c|}{ Type } & \multirow{2}{*}{ Total } \\
\hline & & & & 1 & 2 & 3 & \\
\hline \multirow{16}{*}{ Common } & \multirow{16}{*}{ All } & Process integration & {$[22,42,53]$} & 1 & & & 1 \\
\hline & & Recycling & {$[22,26,41,61,90,92,94,96,103,104]$} & 2 & & 4 & 6 \\
\hline & & Management of flows & {$[26,92]$} & 1 & & & 1 \\
\hline & & Storage and handling & {$[26,61,74,78,89,92,96,105]$} & 13 & 4 & 1 & 18 \\
\hline & & Planning and scheduling & {$[21,26,29,30,41,47,48,53,55,74,78,86-89]$} & & 5 & & 5 \\
\hline & & Insulation & {$[22,28,40,63,96]$} & 1 & & & 1 \\
\hline & & Tidiness and housekeeping & {$[26,40-42,53,61,89,92,94,96]$} & & 2 & & 2 \\
\hline & & Maintenance & {$[26,40-42,50,52,53,61,87,89,92,94,96]$} & & 6 & & 6 \\
\hline & & Noise mitigation & {$[26,92]$} & 4 & 1 & & 5 \\
\hline & & Wastewater management & {$[26,90,92,96]$} & 5 & 2 & 1 & 8 \\
\hline & & Equipment layout & {$[41,61,105]$} & 3 & & & 3 \\
\hline & & Yield & {$[26,41,46,47,55,61,63,69,85,86,92]$} & 1 & 2 & & 3 \\
\hline & & Air emission management & {$[26,41,46,55,74,89,90,92,96]$} & 9 & 7 & 1 & 17 \\
\hline & & Control of processes & {$[42,53]$} & & 2 & & 2 \\
\hline & & Heat recovery & {$[12,22,26,28-31,40-42,46,47,52,53,55,59,63,69,74,86,92,96,106-108]$} & & & 2 & 2 \\
\hline & & Decommissioning & [26] & 1 & & & 1 \\
\hline \multirow{31}{*}{ Step-specific } & \multirow{15}{*}{ Melting } & Equipment layout & {$[12,13,41,42,46,55,59,74,78,105]$} & 4 & & 1 & 5 \\
\hline & & Maintenance & {$[3,26,30,41,42,46,50,52,55,61,63,69,74,78,87,92,96,105,109]$} & 1 & 5 & & 6 \\
\hline & & Planning and scheduling & {$[11-13,26-30,41,52,53,58,59,61,63,74,75,78,83,86,92,105,107]$} & & 8 & & 8 \\
\hline & & Heat recovery & [74] & & & 1 & 1 \\
\hline & & Tidiness and housekeeping & {$[41,55]$} & & 2 & & 2 \\
\hline & & Insulation & {$[12,13,26-30,39,41,42,46,50,52,55,59,61,63,69,74,78,83,92,105,108,109]$} & 4 & 2 & & 6 \\
\hline & & Procedures and training & {$[26,28,29,46,74,105,109]$} & & 3 & & 3 \\
\hline & & Power management & {$[12,13,26-29,42,46,55,58,63,69,74,78,86,87,92,96,105,108]$} & 5 & 9 & & 14 \\
\hline & & Melting temperature & {$[12,26,28,29,41,42,46,55,69,74,78,92,96,105,109]$} & & 4 & & 4 \\
\hline & & Air-fuel ratio & {$[42,55,96]$} & 1 & & & 1 \\
\hline & & Air emission management & {$[26,92,96,108]$} & 2 & 1 & & 3 \\
\hline & & Monitoring & {$[28,29,41,109]$} & 1 & 1 & & 2 \\
\hline & & Feedstock & $\begin{array}{l}{[12,22,26-30,41,46,50,52,53,55,58,61,69,74,78,87,92,94,96,105,107,109]}\end{array}$ & 1 & 8 & & 9 \\
\hline & & Slag & {$[26,74,78,87,92,109]$} & & 3 & & 3 \\
\hline & & Charging & {$[12,26,27,30,41,53,55,61,74,78,92,105,109]$} & & 17 & & 17 \\
\hline & \multirow{9}{*}{ Moulding } & Lubricants, solvents, and coatings & {$[26,89,92,96]$} & 4 & & & 4 \\
\hline & & Binder use & {$[26,55,61,89,90,92,96,110]$} & 2 & 11 & & 13 \\
\hline & & Sand management & {$[26,41,61,63,87,89,90,92,96,102,103]$} & 4 & 5 & 3 & 12 \\
\hline & & Cores & {$[26,41,46,59,92,103]$} & 6 & 2 & & 8 \\
\hline & & Flasks & [61] & & 2 & & 2 \\
\hline & & Ovens & [41] & 2 & & & 2 \\
\hline & & Air emission management & {$[26,89,90,92,96]$} & 2 & & & 2 \\
\hline & & Design & [41] & 1 & 1 & & 2 \\
\hline & & Tidiness and housekeeping & {$[26,92,96]$} & & 1 & & 1 \\
\hline & \multirow{4}{*}{ Casting } & Design & {$[26,30,41,53,55,59,61,69]$} & 1 & 4 & & 5 \\
\hline & & Air emission management & {$[26,89,90,92]$} & 2 & & & 2 \\
\hline & & Sand management & [61] & 1 & & & 1 \\
\hline & & Ladles & {$[12,26,28,30,41,46,50,52,53,55,61,63,69,78,87,92,105]$} & 4 & 7 & & 11 \\
\hline & \multirow{3}{*}{ Finishing } & Air emission management & {$[26,89,92]$} & 3 & & & 3 \\
\hline & & Heat treatment furnace & {$[26,41,52,63]$} & 6 & 5 & 1 & 12 \\
\hline & & Noise mitigation & [92] & 3 & & & 3 \\
\hline \multirow{13}{*}{$\begin{array}{l}\text { Utilities and } \\
\text { services }\end{array}$} & & General & {$[13,21,22,41,42,48,55,61-63,74,78,89,92,96,110,111]$} & 2 & 3 & & 5 \\
\hline & & Compressed air & {$[13,21,22,29,30,40-42,46,50,52,53,55,63,78,83,86,87,110-112]$} & 13 & 5 & 1 & 19 \\
\hline & & Lighting & {$[21,29,30,40-42,46,52,53,55,61,62,78,110,111]$} & 9 & 9 & & 18 \\
\hline & & $\begin{array}{l}\text { Heating, ventilation, and air } \\
\text { conditioning }\end{array}$ & {$[26,40-42,46,52,53,55,78,96,110]$} & 18 & 13 & 1 & 32 \\
\hline & & Pumps & {$[42,55,78,92]$} & 16 & 3 & & 19 \\
\hline & - & Steam systems & {$[42,46,104]$} & 5 & 7 & 5 & 17 \\
\hline & & Fuel & {$[22,26,40,42,47,53,96,104,113]$} & 3 & & 1 & 4 \\
\hline & & Chillers and cooling systems & {$[40,46,53,78]$} & 3 & 4 & & 7 \\
\hline & & Electrical distribution system & {$[13,62,87,111]$} & 2 & 7 & & 9 \\
\hline & & Water & {$[26,41,61,90,92,96]$} & 8 & 3 & 2 & 13 \\
\hline & & Vacuum & [46] & 2 & & & 2 \\
\hline & & $\begin{array}{l}\text { Vehicle movements and } \\
\text { transportation }\end{array}$ & {$[26,41,42,92]$} & 2 & 4 & & 6 \\
\hline & & & Total & 184 & 190 & 25 & 399 \\
\hline
\end{tabular}

\section{Discussion}

Two main categories of practices could be identified in the literature: general management practices and specific practices. 
The general management practices consist of high-level cross-industry principles that deal mainly with the adoption of a management system and its essential elements. Indeed, one of the most promising means of reducing energy consumption and related energy costs is implementing energy management in an organisation [16]. A formal energy management system could be certified according to standard ISO 50001 [2]. Analogously, a formal environmental management system could be certified according to ISO 14001 [5]. Although these general practices represent the set of requirements to implement a management system for improving energy and environmental performances, they can also be adopted individually. The themes are those characteristic of all management systems: policy and programs; audits; monitoring, measurement and control; benchmarking; training, communication and involvement; continual improvement; modelling and simulation; manager and/or team.

The second category of practices includes specific practices, i.e., specific activities, procedures, and routines that represent the translation of general energy and environmental management principles into more specific operating instructions. A total of 399 specific practices have been identified through our literature review. They can be further divided into three groups: 81 practices common to all process steps in a cast iron foundry, 167 practices step-specific, 151 practices for utilities and support processes.

Among the management practices common to all foundry process steps, storage and handling, air emission management, wastewater management, maintenance, and recycling appear as the themes with the highest number of practices proposed in the literature. Almost all of them deal mainly with environmental impact. For example, careful storage and handling of materials inside a foundry could reduce the spill risks and minimise dust emissions. Only maintenance concerns mainly with energy efficiency. High interest in the maintenance practice is justified by the fact that investments in energy efficient technology generate improved efficiencies, but without maintenance and continuous monitoring the total efficiency potential cannot be attained [15].

As expected, the largest number of step-specific practices is found in the melting department (84 practices). Indeed, the energy efficiency of any metal casting facility depends largely on the melting processes $[13,30]$, since induction furnaces are responsible for up to $80 \%$ of the whole energy consumption of the factory [110]. In the set of melting practices, charging takes on particular importance: the majority of the emissions occurs during charging and depends on the charged material's cleanliness and composition.

The third group of specific practices relates to utilities and support processes. Although the energy need for service plants represents in a foundry a minor fraction, around $5 \%-10 \%$ of the whole energy consumption, the absolute amounts are relevant [111]. The utilities with the highest number of practices available for the foundry process to improve energy efficiency and reduce adverse environmental impact are heating, ventilation and air conditioning, compressed air, and pumps. This is not surprising since these are all among the most energy-consuming services in a cast iron foundry [110]. On the contrary, it seems that only limited attention in the literature has been devoted to lighting, steam systems, and cooling systems despite the significant energy consumption required for their operation. In addition, only a very few practices are available for the vacuum and transportation systems. The large majority of the practices related to service plants identified for cast iron foundry could also be adopted in other production contexts. The opposite way is also true. Since service plants are recognised as important areas for efficiency improvements in many other industrial and commercial sectors, future research could focus on identifying service plant management practices in other industries and suggest their use in foundry.

Unfortunately, the level of detail provided by the literature for the different practices is not homogeneous. Some practices are high level and generic, e.g., "Select less noisy engineering equipment", others very specific and detailed, e.g., "Invert pouring ladles $90^{\circ}$ or $180^{\circ}$ prior to heating". In the first case, the practice could be difficult to implement because it does not provide guidance on how to carry out the activity; in the second case it could be risky to implement the practice because it is not clear whether the strict advice is valid in every context or subject to some specific conditions. 
The expected outcome of each practice or the effort required for its implementation are discussed only by a few reference sources and usually in qualitative terms. This is the reason why this information has not been summarised in this review. However, this represents a major gap in the literature, since it is not possible to clearly prioritise which practices to adopt based on the ratio between implementation cost and potential benefits in terms of energy efficiency or adverse environmental impact reduction.

In order to partially overcome this prioritisation issue, an attempt has been made in this paper to classify the different practices according to their sustainability. Type 1 practices represent the most preferable alternative because they aim at eliminating an energy demand or environmental impact altogether. Type 2 practices are the second choice from a sustainability point of view since they only try to reduce or minimise the consumption of resources, while Type 3 are the least preferable category because they only focus on the reuse, recycling, or recovery of resources. The large majority of the practices identified in our review have been classified as Type 1 (184) or Type 2 (190), while only 25 practices are Type 3 . This result is encouraging since it suggests that energy efficiency and environmental impact reduction in cast iron foundries are approached mainly through highly sustainable practices. The high maturity of the foundry industry and its increasing awareness towards sustainability issues are confirmed also by the large number of practices identified and the wide range of themes covered.

\section{Conclusions}

We conducted a scoping literature review of the management practices for energy efficiency improvement and adverse environmental impact reduction in cast iron foundries. A large number of practices suitable for each foundry production and non-production process have been returned by the review. These have then been classified according to theme, process step of applicability, and sustainability type.

The main contribution of this paper is having highlighted the possibility of achieving energy efficiency improvement and adverse environmental impact reduction without the need of costly technology investments, promoting the adoption of management practices as an effective lever to this aim. The review has demonstrated that a multitude of practices are available, either specific to the foundry industry or applicable across all industries. Furthermore, the summary tables of results may represent a valuable instrument for managers interested in appropriately selecting and implementing the most suitable practices for achieving energy savings and enhancing environmental performance to improve sustainability in foundries' activities.

Another contribution has been the proposal of a reference framework for the classification of practices according to their sustainability. The results have shown that the practices proposed in the literature focus mainly on avoiding or reducing resource consumption, rather than on recovering residual value, thus confirming the high maturity of the foundry industry. The classification could also help practitioners in the difficult task of prioritising the practices to implement.

Unfortunately, we could not discuss in depth each identified practice, but the list of references provides useful and additional insights for a proper adoption of every practice. Since the quantity of data to manage was huge, breadth (trying to cover all available material) was considered more important than depth (providing a detailed analysis and appraisal of a smaller number of studies). However, due to the broadness of the research questions, some studies of interest could have been overlooked. Among the limitations of scoping studies, and also of this review, are the lack of formal appraisal of the quality of included research and the issue of 'synthesis', i.e., the possibility to provide only a narrative description of results.

Future research could overcome the limitations of this paper, for example investigating the effort required to implement each practice. Data on the potential benefits in terms of energy efficiency improvement and adverse environmental impact reduction achievable by the company through the implementation of each single practice should also be collected. 
Supplementary Materials: The following are available online at http:/www.mdpi.com/2071-1050/11/24/7245/s1, Table S1: Management practices for all foundry process steps; Table S2: Management practices specific for each foundry process step; Table S3: Management practices for utilities and services management.

Author Contributions: P.C. and F.M. proposed and designed the research, wrote, and revised the manuscript; E.S. conducted the review, collected, and analysed the papers; D.R. proposed the summary tables, conducted discussions, and proofread the manuscript; G.T. provided some comments and helped to edit the manuscript. All authors revised and approved the final manuscript.

Funding: This research was funded by Regione Lombardia, grant number 29942922.

Conflicts of Interest: The authors declare no conflict of interest.

\section{References}

1. Mardan, N.; Klahr, R. Combining optimisation and simulation in an energy systems analysis of a Swedish iron foundry. Energy 2012, 44, 410-419. [CrossRef]

2. International Organization for Standardization. ISO 50001: Energy Management Systems—Requirements with Guidance for Use; International Organization for Standardization: Geneva, Switzerland, 2018.

3. Sa, A.; Paramonova, S.; Thollander, P.; Cagno, E. Classification of Industrial Energy Management Practices -A case study of a Swedish Foundry. Energy Procedia 2015, 75, 2581-2588. [CrossRef]

4. Saygin, D.; Worrell, E.; Patel, M.K.; Gielen, D.J. Benchmarking the energy use of energy-intensive industries in industrialized and in developing countries. Energy 2011, 36, 6661-6673. [CrossRef]

5. International Organization for Standardization. ISO 14001: Environmental Management Systems_Requirements with Guidance for Use; International Organization for Standardization: Geneva, Switzerland, 2015.

6. Remus, R.; Aguado Monsonet, M.A.; Roudier, S.; Delgado Sancho, L. JRC reference Report. In Best Available Techniques (BAT) Reference Document for Iron and Steel Production; Joint Research Centre of the European Commission: Luxembourg, 2013.

7. Olmez, G.M.; Dilek, F.B.; Karanfil, T.; Yetis, U. The environmental impacts of iron and steel industry: A life cycle assessment study. J. Clean. Prod. 2016, 130, 195-201. [CrossRef]

8. Sustainability Accounting Standards Board. Iron E Steel Producers, Research Brief; Sustainability Accounting Standards Board: San Francisco, CA, USA, 2014.

9. U.S. Energy Information Administration. International Energy Outlook 2016; U.S. Energy Information Administration, Office of Energy Analysis U.S. Department of Energy: Washington County, OR, USA, 2016.

10. European Commission. Strategic Energy Technologies Information System (SETIS). Energy Efficiency and $\mathrm{CO}_{2}$ Reduction in the Iron and Steel Industry. Available online: https: //setis.ec.europa.eu/system/files/Technology_Information_Sheet_Energy_Efficiency_and_CO2_Reduction_ in_the_Iron_and_Steel_Industry.pdf (accessed on 11 November 2019).

11. Arasu, M.; Jeffrey, L.R. Energy consumption studies in cast iron foundries. In Proceedings of the Transactions of 57th Indian Foundry Congress, Kolkata, India, 13-15 February 2009; pp. 331-336.

12. BCS Incorporated. Advanced Melting Technologies: Energy Saving Concepts and Opportunities for the Metal Casting Industry; US Department of Energy, Office of Energy Efficiency and Renewable Energy: Columbia, MD, USA, 2005.

13. Patange, G.; Khond, M. Some studies on energy consumptions and identification of suitable energy management techniques in Indian foundry industries. Eur. Sci. J. 2013, 9, 241-252. [CrossRef]

14. Lo, K.; Li, H.; Wang, M. Energy conservation in China's energy-intensive enterprises: An empirical study of the Ten-Thousand Enterprises Program. Energy Sustain. Dev. 2015, 27, 105-111. [CrossRef]

15. Backlund, S.; Thollander, P.; Palm, J.; Ottosson, M. Extending the energy efficiency gap. Energy Policy 2012, 51, 392-396. [CrossRef]

16. Schulze, M.; Nehler, H.; Ottosson, M.; Thollander, P. Energy management in industry-A systematic review of previous findings and an integrative conceptual framework. J. Clean. Prod. 2016, 112, 3692-3708. [CrossRef]

17. Rohdin, P.; Thollander, P.; Solding, P. Barriers to and drivers for energy efficiency in the Swedish foundry industry. Energy Policy 2007, 35, 672-677. [CrossRef]

18. Trianni, A.; Cagno, E.; Thollander, P.; Backlund, S. Barriers to industrial energy efficiency in foundries: A European comparison. J. Clean. Prod. 2013, 40, 161-176. [CrossRef] 
19. Caffall, C. Learning from Experiences with Energy Management in Industry; Centre for the Analysis and Dissemination of Demonstrated Energy Technologies: Sittard, The Netherlands, 1995.

20. Christoffersen, L.B.; Larsen, A.; Togeby, M. Empirical analysis of energy management in Danish industry. J. Clean. Prod. 2006, 14, 516-526. [CrossRef]

21. Cagno, E.; Trianni, A. Analysis of the most effective energy efficiency opportunities in manufacturing primary metals, plastics, and textiles small-and medium-sized enterprises. J. Energy Resour. Technol. 2012, 134. [CrossRef]

22. Intergovernmental Panel on Climate Change. Climate Change 2007: Mitigation. In Contribution of Working Group III to the Fourth Assessment Report of the Intergovernmental Panel on Climate Change; Metz, B., Davidson, O.R., Bosch, P.R., Dave, R., Meyer, L.A., Eds.; Cambridge University Press: Cambridge, UK; New York, NY, USA, 2007.

23. Yang, M.G.M.; Hong, P.; Modi, S.B. Impact of lean manufacturing and environmental management on business performance: An empirical study of manufacturing firms. Int. J. Prod. Econ. 2011, 129, 251-261. [CrossRef]

24. Thollander, P.; Ottosson, M. Energy management practices in Swedish energy-intensive industries. J. Clean. Prod. 2010, 18, 1125-1133. [CrossRef]

25. Schleich, J. Barriers to energy efficiency: A comparison across the German commercial and services sector. Ecol. Econ. 2009, 68, 2150-2159. [CrossRef]

26. European Commission. Integrated Pollution Prevention and Control-Reference Document on Best Available Techniques in the Smitheries and Foundries Industry; European Commission: Brussels, Belgium, 2005.

27. Gandhewar, V.R.; Bansod, S.V.; Borade, A.B. Induction Furnace-A Review. Int. J. Eng. Technol. 2011, 3, 277-284.

28. Lazzarin, R.M.; Noro, M. Energy efficiency opportunities in the production process of cast iron foundries: An experience in Italy. Appl. Therm. Eng. 2015, 90, 509-520. [CrossRef]

29. Noro, M.; Lazzarin, R.M. Energy audit experiences in foundries. Int. J. Energy Environ. Eng. 2016, 7, 409-423. [CrossRef]

30. Eppich, R.E.; Naranjo, R.D. Implementation of Metal Casting Best Practices; US Department of Energy, Office of Energy Efficiency and Renewable Energy: Washington, DC, USA, 2007.

31. Muthuraman, L.V. Energy Conservation in Foundries Using Waste Heat Recovery System. Procedia Eng. 2014, 97, 1842-1852. [CrossRef]

32. Rodríguez, A.; López de Lacalle, L.N.; Calleja, A.; Fernández, A.; Lamikiz, A. Maximal reduction of steps for iron casting one-of-a-kind parts. J. Clean. Prod. 2012, 24, 48-55. [CrossRef]

33. Arksey, H.; O'Malley, L. Scoping studies: Towards a methodological framework. Int. J. Soc. Res. Methodol. 2005, 8, 19-32. [CrossRef]

34. Colquhoun, H.L.; Levac, D.; O’Brien, K.K.; Straus, S.; Tricco, A.C.; Perrier, L.; Kastner, M.; Moher, D. Scoping reviews: Time for clarity in definition, methods, and reporting. J. Clin. Epidemiol. 2014, 67, 1291-1294. [CrossRef] [PubMed]

35. Antman, E.; Lau, J.; Kupeinick, B.; Mosteller, F.; Chalmers, T. A comparison of results of meta-analysis of RCTs and recommendations of clinical experts. J. Am. Med. Assoc. 1992, 268, 240-248. [CrossRef]

36. European Parliament and Council. Directive 2008/98/EC of the European Parliament and of the Council of 19 November 2008 on waste and repealing certain Directives. Off. J. Eur. Union 2008, L 312, 3-30. Available online: https://eur-lex.europa.eu/legal-content/EN/TXT/?uri=celex\%3A32008L0098 (accessed on 17 December 2019).

37. Enright, N. The Resource Efficiency Hierarchy. 2013. Available online: https://www.sustainsuccess.co.uk/ the-resource-efficiency-hierarchy (accessed on 28 November 2019).

38. Ates, S.A.; Durakbasa, N.M. Evaluation of corporate energy management practices of energy-intensive industries in Turkey. Energy 2012, 45, 81-91. [CrossRef]

39. Bhalke, S.; Chate, G.; Kallol, A.; Humbarwadi, S.; Riyaz, M. Energy Auditing of Foundries. Adv. Eng. Appl. Sci. 2015, 5, 74-78.

40. Caballero, P. D21 Good practice guide on energy saving potentials and opportunities for foundries. Foundrybench Foundry Energy Efficiency Benchmarking project (IEE/07/585/SI2.500402), Foundrybench_D21_20122011 project report. 2011. Available online: https:/ec.europa.eu/energy/intelligent/projects/en/projects/ foundrybench (accessed on 17 December 2019). 
41. Canadian Industry Program for Energy Conservation. Guide to Energy Efficiency Opportunities in Canadian Foundries; Canadian Foundry Association: Ottawa, ON, Canada, 2003.

42. European Commission. Reference Document on Best Available Techniques for Energy Efficiency; European Commission: Brussels, Belgium, 2009.

43. European Committee for Standardization. EN 15900. Energy Efficiency Services-Definitions and Requirements; European Committee for Standardization: Brussels, Belgium, 2010.

44. European Committee for Standardization. EN 16247-4. Energy Audits_Part 4: Transport; European Committee for Standardization: Brussels, Belgium, 2014.

45. Fawkes, S.; Oung, K.; Thorpe, D. Best Practices and Case Studies for Industrial Energy Efficiency Improvement-An Introduction for Policy Makers; UNEP DTU Partnership: Copenhagen, Denmark, 2016.

46. Bettinghaus, J.; Kunes, T.P.; Nicol, J.; Presny, D.; Schepp, C.; Altfeather, N. Metal Casting Industry Energy Best Practice Guidebook; State of Wisconsin, Department of Administration, Division of Energy: Madison, WI, USA, 2006.

47. Jarża, S. Importance of Energy Management in foundries. Policy J. Manag. Stud. 2011, 4, 166-173.

48. Lee, D.; Cheng, C.-C. Energy savings by energy management systems: A review. Renew. Sustain. Energy Rev. 2016, 56, 760-777. [CrossRef]

49. O'Callaghan, P.W.; Probert, S.D. Energy management. Appl. Energy 1977, 3, 127-138. [CrossRef]

50. Prashanth, M.S.; Eshwar, R.; Patel, V.K.; Selvaraj, J.; Rohit, R.; Rahul, R.; Menon, G.K. A Multi Faceted Approach To Energy Conservation In Foundries. Procedia Eng. 2014, 97, 1815-1824. [CrossRef]

51. Brunke, J.-C.; Johansson, M.; Thollander, P. Empirical investigation of barriers and drivers to the adoption of energy conservation measures, energy management practices and energy services in the Swedish iron and steel industry. J. Clean. Prod. 2014, 84, 509-525. [CrossRef]

52. Eronen, S.; Tapola, M.; Svensson, E.; Sommarin, P.; Helber, J.; Piatek, J.-M.; Przybylski, J.; Caballero, P.; Kemppainen, P. Improving the energy efficiency of foundries in Europe. Foundrybench - Foundry Energy Efficiency Benchmarking project (IEE/07/585/SI2.500402), final project report. 2012. Available online: https:/ec.europa.eu/energy/intelligent/projects/en/projects/foundrybench (accessed on 17 December 2019).

53. Helber, J.; Steinhäuser, M. D19 Good practice guide on energy saving potentials and opportunities for foundries. Foundrybench - Foundry Energy Efficiency Benchmarking project (IEE/07/585/SI2.500402), Foundrybench_D19_12122011 project report. 2011. Available online: https://ec.europa.eu/energy/intelligent/ projects/en/projects/foundrybench (accessed on 17 December 2019).

54. Institute for Industrial Productivity. Best Practices in Energy Efficient Industrial Technologies-Iron and Steel; Fraunhofer Institute for Systems and Innovation Research ISI: Karlsruhe, Germany, 2011.

55. Kermeli, K.; Deuchler, R.; Worrell, E.; Masanet, E. Energy Efficiency and Cost Saving Opportunities for Metal Casting-An ENERGY STAR Guide for Energy and Plant Managers; US Environmental Protection Agency: Washington, DC, USA, 2016.

56. McKane, A.; Perry, W.; Li, A.; Li, T.; Williams, R. Creating a standard framework for sustainable industrial energy efficiency. In Proceedings of the Conference Proceedings of Energy Efficiency in Motor Driven Systems (EEMDS 2005), Heidelberg, Germany, 5-8 September 2005; pp. 218-228.

57. Thollander, P.; Backlund, S.; Trianni, A.; Cagno, E. Beyond barriers-A case study on driving forces for improved energy efficiency in the foundry industries in Finland, France, Germany, Italy, Poland, Spain, and Sweden. Appl. Energy 2013, 111, 636-643. [CrossRef]

58. Carbon Trust. Energy Management. In A Comprehensive Guide to Controlling Energy Use; CTG054; Carbon Trust: London, UK, 2011.

59. Cagno, E.; Ramirez-Portilla, A.; Trianni, A. Linking energy efficiency and innovation practices: Empirical evidence from the foundry sector. Energy Policy 2015, 83, 240-256. [CrossRef]

60. Devi, D.B.; Shinde, N.N. Improvement in Energy Efficiency in Foundry Industry Using Energy Management Practices and Energy Conservation. In Proceedings of the Conference Proceedings of 4th Thermal Power India, New Delhi, India, 28-29 January 2010.

61. Centric Austria International. Cleaner Production in the Foundry Industry of the People's Republic of China-Textbook-Part 5 Cleaner Production Ideas for the Foundry Industry; Centric Austria International: Wien, Austria, 2005.

62. Chan, D.Y.-L.; Yang, K.-H.; Lee, J.-D.; Hong, G.-B. The case study of furnace use and energy conservation in iron and steel industry. Energy 2010, 35, 1665-1670. [CrossRef] 
63. Energy Center of Wisconsin. The Foundry Industry—Review of Process Energy Use, Markets, and Information Resources; Report 155-1; Energy Center of Wisconsin: Madison, WI, USA, 1997.

64. European Committee for Standardization. EN 16247-1. Energy Audits_Part 1: General Requirements; European Committee for Standardization: Brussels, Belgium, 2012.

65. European Committee for Standardization. EN 16247-2. Energy Audits_Part 2: Buildings; European Committee for Standardization: Brussels, Belgium, 2014.

66. European Committee for Standardization. EN 16247-3. Energy Audits_Part 3: Processes; European Committee for Standardization: Brussels, Belgium, 2014.

67. European Committee for Standardization. EN 16247-5. Energy Audits_Part 5: Competence of Energy Auditors; European Committee for Standardization: Brussels, Belgium, 2015.

68. International Organization for Standardization. ISO 19001: Guidelines for Auditing Management Systems; International Organization for Standardization: Geneva, Switzerland, 2018.

69. Schifo, J.F.; Radia, J.T. Theoretical/Best Practice Energy Use in Metalcasting Operations; US Department of Energy, Office of Energy Efficiency and Renewable Energy: Washington, DC, USA, 2004.

70. Thollander, P.; Mardan, N.; Karlsson, M. Optimization as investment decision support in a Swedish medium-sized iron foundry-A move beyond traditional energy auditing. Appl. Energy 2009, 86, 433-440. [CrossRef]

71. International Organization for Standardization. ISO 50003: Energy Management Systems—Requirements for Bodies Providing Audit and Certification of Energy; International Organization for Standardization: Geneva, Switzerland, 2014.

72. European Committee for Standardization. EN 16212. Energy Efficiency and Savings Calculation. In Top-Down and Bottom-Up Methods; European Committee for Standardization: Brussels, Belgium, 2012.

73. International Organization for Standardization. ISO 50006: Energy Management Systems—Measuring Energy Performance Using Energy Baselines (EnB) and Energy Performance Indicators (EnPI)—General Principles and Guidance; International Organization for Standardization: Geneva, Switzerland, 2014.

74. Energy Technology Support Unit. Efficient Melting in Coreless Induction Furnaces-Good Practice Guide 50; Energy Efficiency Best Practice Programme: London, UK, 2000.

75. Giacone, E.; Mancò, S. Energy efficiency measurement in industrial processes. Energy 2012, 38, 331-345. [CrossRef]

76. International Organization for Standardization. ISO 50015: Energy Management Systems_Measurement and Verification of Energy Performance of Organizations—General Principles and Guidance; International Organization for Standardization: Geneva, Switzerland, 2014.

77. Kim, Y.; Worrell, E. International comparison of $\mathrm{CO}_{2}$ emission trends in the iron and steel industry. Energy Policy 2002, 30, 827-838. [CrossRef]

78. TERI; COINDIA. Energy Efficiency Best Operating Practices Guide for Foundries; The Energy and Resources Institute: New Delhi, India; Coimbatore Industrial Infrastructure Association: Tamil Nadu, India, 2015.

79. Worrell, E.; Price, L.; Martin, N.; Farla, J.; Schaeffer, R. Energy intensity in the iron and steel industry: A comparison of physical and economic indicators. Energy Policy 1997, 25, 727-744. [CrossRef]

80. Yoon, H.-S.; Lee, J.-Y.; Kim, H.-S.; Kim, M.-S.; Kim, E.-S.; Shin, Y.-J.; Chu, W.-S.; Ahn, S.-H. A comparison of energy consumption in bulk forming, subtractive, and additive processes: Review and case study. Int. J. Precis. Eng. Manuf. Green Technol. 2014, 1, 261-279. [CrossRef]

81. Yuanyuan, L.; Weiping, C.; Dan, H.; Jie, L.; Zhe, L.; Yongcheng, C.; Qiping, L.; Shifang, S. Energy conservation and emissions reduction strategies in foundry industry. China Foundry 2010, 7, 392-399.

82. European Committee for Standardization. EN 16231. Energy Efficiency Benchmarking Methodology; European Committee for Standardization: Brussels, Belgium, 2012.

83. Eppich, R.E. Energy Use in Selected Metalcasting Facilities-2003; US Department of Energy, Office of Energy Efficiency \& Renewable Energy: Washington County, OR, USA, 2004.

84. Worrell, E.; Price, L. An Integrated Benchmarking and Energy Savings Tool for the Iron and Steel Industry. Int. J. Green Energy 2006, 3, 117-126. [CrossRef]

85. Solding, P.; Thollander, P. Increased energy efficiency in a Swedish iron foundry through use of discrete event simulation. In Proceedings of the 2006 Winter Simulation Conference, Monterey, CA, USA, 3-6 December 2006; pp. 1971-1976. 
86. Thollander, P.; Karlsson, M.; Söderström, M.; Creutz, D. Reducing industrial energy costs through energy efficiency measures in a liberalized European electricity market: Case study of a Swedish iron foundry. Appl. Energy 2005, 81, 115-126. [CrossRef]

87. Arjunwadkar, S.H.; Ransing, M.R.; Ransing, R.S. Seven Steps to Energy Efficiency for Foundries. Foundry Manag. Technol. 2015, 143, 24-29.

88. Centric Austria International. Cleaner Production in the Foundry Industry of the People's Republic of China-Textbook-Part 6 Sustain CP (Cleaner Production) in the Company; Centric Austria International: Wien, Austria, 2005.

89. DEFRA. Process Guidance Note 2/04-Statutory Guidance for Iron, Steel and Non-Ferrous Foundry Processes; UK Department for Environment, Food \& Rural Affairs: London, UK, 2013.

90. Environment Protection Authority. Environmental Management of Foundries - EPA 121/16 Guideline; Environment Protection Authority: Adelaide, SA, Australia, 2016.

91. Ribeiro, L.M.M.; Cabral, J.A.S. A benchmarking methodology for metalcasting industry. Benchmarking Int. J. 2006, 13, 23-35. [CrossRef]

92. Environmental Protection Agency. Final Draft BAT Guidance Note on Best Available Techniques for Ferrous Metal Foundries; Environmental Protection Agency: Wexford, Ireland, 2012.

93. European Parliament and Council. Regulation (EC) No 1221/2009 of the European Parliament and of the Council of 25 November 2009 on the voluntary participation by organisations in a Community eco-management and audit scheme (EMAS), repealing Regulation (EC) No 761/2001 and Commission Decisions 2001/681/EC and 2006/193/EC. Off. J. Eur. Union 2009, L 342, 1-45. Available online: https://eur-lex.europa.eu/legal-content/EN/TXT/?uri=CELEX\%3A32009R1221 (accessed on 17 December 2019).

94. Secretariat of the Stockholm Convention. Revised Draft Guidelines on Best Available Techniques and Provisional Guidance on Best Environmental Practices Relevant to Article 5 and Annex C of the Stockholm Convention on Persistent Organic Pollutants; UNEP (United Nations Environment Programme): Geneva, Switzerland, 2006.

95. Centric Austria International. Cleaner Production in the Foundry Industry of the People's Republic of China-Textbook-Part 4 Embodiment of Cleaner Production in the Company; Centric Austria International: Wien, Austria, 2005.

96. International Finance Corporation; Word Bank Group. Environmental, Health, and Safety Guidelines for Foundries; International Finance Corporation, Word Bank Group: Washington, DC, USA, 2007.

97. International Organization for Standardization. ISO 14031: Environmental Management-Environmental Performance Evaluation - Guidelines; International Organization for Standardization: Geneva, Switzerland, 2013.

98. International Organization for Standardization. ISO/TS 14033: Environmental Management-Quantitative Environmental Information-Guidelines and Examples; International Organization for Standardization: Geneva, Switzerland, 2012.

99. Verfaillie, H.A.; Bidwell, R. Measuring Eco-Efficiency: A Guide to Reporting Company Performance; World Business Council for Sustainable Development: Geneva, Switzerland, 2000.

100. International Organization for Standardization. ISO 14040: Environmental Management-Life Cycle Assessment-Principles and Framework; International Organization for Standardization: Geneva, Switzerland, 2006.

101. International Organization for Standardization. ISO 14044: Environmental Management-Life cycle Assessment-Requirements and Guidelines (Including Amd 1:2017); International Organization for Standardization: Geneva, Switzerland, 2006.

102. Yilmaz, O.; Anctil, A; Karanfil, T. LCA as a decision support tool for evaluation of best available techniques (BATs) for cleaner production of iron casting. J. Clean. Prod. 2015, 105, 337-347. [CrossRef]

103. Dalquist, S.; Gutowski, T. Life cycle analysis of conventional manufacturing techniques: Sand casting. In Proceedings of the ASME 2004 International Mechanical Engineering Congress and Exposition, Anaheim, CA, USA, 13-19 November 2004; pp. 631-641. [CrossRef]

104. Brown, T.; Gambhir, A.; Florin, N.; Fennell, P. Reducing $\mathrm{CO}_{2}$ Emissions from Heavy Industry: A Review of Technologies and Considerations for Policy Makers; Grantham Institute for Climate Change, Imperial College London: London, UK, 2012. 
105. United Nations Industrial Development Organization; Japanese Ministry of International Trade and Industry. Seminar on Energy Conservation in Iron Casting Industry; United Nations Industrial Development Organization: Hanoi, Vietnam; Japanese Ministry of International Trade and Industry: Tokyo, Japan, 1998.

106. Chen, L.; Yang, B.; Shen, X.; Xie, Z.; Sun, F. Thermodynamic optimization opportunities for the recovery and utilization of residual energy and heat in China's iron and steel industry: A case study. Appl. Therm. Eng. 2015, 86, 151-160. [CrossRef]

107. US Environmental Protection Agency. Energy Trends in Selected Manufacturing Sectors: Opportunities and Challenges for Environmentally Preferable Energy Outcomes; US Environmental Protection Agency: Wasington, DC, USA, 2007.

108. Holtzer, M. Influence of the cast iron melting processes on environment using BAT. Arch. Foundry Eng. 2007, 7, 83-88.

109. Energy Technology Support Unit. Holding Molten Iron in Electric Furnaces—Good Practice Guide 68; Energy Efficiency Best Practice Programme: London, UK, 2000.

110. Gigante, G. Becoming a Practical Green Casting Industry. Mod. Cast. 2011, 101, 38-41.

111. Lazzarin, R.M.; Noro, M. Energy efficiency opportunities in the service plants of cast iron foundries in Italy. Int. J. Low Carbon Technol. 2017, 12, 96-109. [CrossRef]

112. Energy Technology Support Unit. Energy Savings in the Selection, Control and Maintenance of Air Compressors_Good Practice Guide 241; Energy Efficiency Best Practice Programme: London, UK, 1998.

113. Abedghars, M.T.; Hadji, A.; Bouhouch, S. Monitoring of air quality in an iron foundry (Case of $\mathrm{NOx}_{2} \mathrm{SO}_{2}$, benzene and dust). J. Mater. Environ. Sci. 2011, 2 (Suppl. S1), 501-506.

(C) 2019 by the authors. Licensee MDPI, Basel, Switzerland. This article is an open access article distributed under the terms and conditions of the Creative Commons Attribution (CC BY) license (http://creativecommons.org/licenses/by/4.0/). 